\title{
Ascorbic acid in the prevention and treatment of cancer
}

\author{
Ana Maria Oliveira Ferreira da Mata ${ }^{1}$, Ricardo Melo de Carvalho ${ }^{1}$, Marcus Vinícius Oliveira Barros de Alencar², \\ Ana Amélia de Carvalho Melo Cavalcante ${ }^{1,2}$, Benedito Borges da Silva ${ }^{1,2 *}$ \\ ${ }^{1}$ Pharmaceutical Science Graduate Program, Universidade Federal do Piaú, Teresina, PI, Brazil \\ ${ }^{2}$ Biotechnology Graduate Program, Rede Nordeste de Biotecnologia (Renorbio), PI, Brazil
}

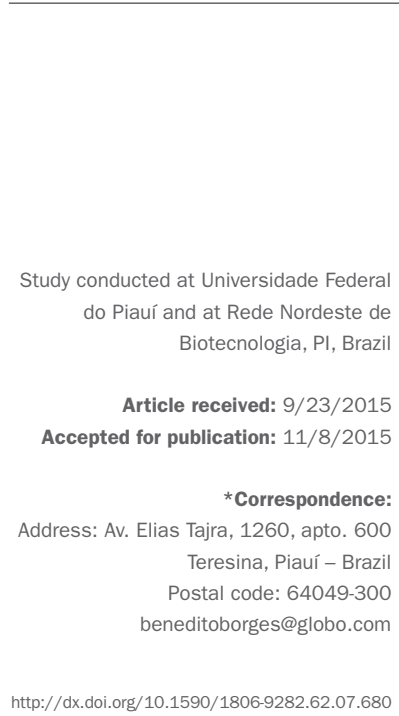

\section{SUMMARY}

This review is aimed at the systematic mapping of ascorbic acid in the prevention and/or treatment of cancer in clinical and non-clinical studies from 2011 to 2015 , in order to understand dose-response variations as well as its mechanisms of action as an antioxidant and antitumor agent. Seventy-eight articles were retrieved from the PubMed/Bireme database, of which only 30 included ascorbic acid in the prevention and/or treatment of cancer. However, there are controversies regarding doses and a lack of clinical studies featuring its mechanism of action more clearly. Other studies are needed to understand dose-response variations, as well as its targeting mechanisms of action, both as an antioxidant and antitumor agent, to assist treatment and prevention of cancer, aiming at better quality of life for both patients and the general population.

Keywords: neoplasms, cancer, prevention, ascorbic acid, antioxidants.

\section{INTRODUCTION}

The word "cancer" derives from the Greek Karkinos, which means crab, a reference to the blood vessels infiltrated in the tumor as if they were the claws of this animal. Currently, cancer is characterized as a complex disease that involves the alteration of gene expression, sustains cell survival and proliferation, and can be modified by genomic and epigenomic factors. ${ }^{1}$ Genomic factors are characterized by changes in the sites of the genes, promoting mutations, while epigenomic factors correspond to changes that do not alter the sequence of DNA bases but their conformation through changes in histone, methylations in DNA bases and nucleosome remodeling., ${ }^{2,3}$

Cancer cells operate under a high level of oxidative stress, due to high baseline levels of reactive oxygen species, oncogenic transformation, and metabolic reprogramming. ${ }^{4}$ Oxidative stress occurs due to imbalance between the production of free radicals [superoxide anion $\left(\mathrm{O}_{2}{ }^{-}\right)$, hydrogen peroxide $\left(\mathrm{H}_{2} \mathrm{O}_{2}\right)$, hydroxyl radical $\left(\mathrm{OH}^{-}\right)$, nitric oxide (NO), and more] and their elimination by antioxidant defense mechanisms [superoxide dismutase (SOD), catalase (CAT), glutathione peroxidase (GPx), among others], which induces cell damage caused by lipid peroxidation generating derangement and loss of function and integrity of the cell membrane, as well as DNA dam- age, promoting genomic instability and cell proliferation, thereby increasing the somatic mutations and neoplastic transformation. 5,6

According to the Brazilian National Cancer Institute (INCA, in the Portuguese acronym), in 2012 there were 14.1 million cases of cancer in the world, with a total of 8.2 million deaths from the disease. It is estimated that in 2030 the global burden of cancer will be 21.4 million new cases and 13.2 million deaths, mainly due to the growth and aging of the population. ${ }^{7}$ Among the types of cancer, breast cancer is the second most common, with a worldwide estimate in 2012 of about 1.67 million new cases. In Brazil, the estimate is about $25 \%$ of all cancer types diagnosed in women. Mortality amounts to $70 \%$ and the 5-year survival ranges from 80 to $40 \%$ depending on the country's economic development. In Brazil, the number of new cases of breast cancer was estimated at 49,000 in $2010 .^{8}$

The etiology of breast cancer is not fully understood; it is multifactorial and includes genetic, reproductive, and environmental factors. The World Health Organization (WHO) states that consumption of fruits and vegetables can help prevent cancer, due to its composition with nutrients such as vitamins, minerals and fiber. ${ }^{9}$ According to the INCA (2011), antioxidant foods, rich in ascorbic acid (vitamin C), carotenoids (vitamin A) and tocopherol 
(vitamin E), selenium, and flavonoids, are recommended due to their antagonistic action, following the requirements presented in the Dietary Reference Intake (DRI), as they can help in the prevention of cancer, inhibiting oxidation and free radical production, and also favoring oxidative stress and even promoting carcinogenesis. ${ }^{10}$

Ascorbic acid (vitamin C) has been widely used in the treatment and prevention of cancer; nevertheless, the clinical results are still inconclusive. At low concentrations, it has an antioxidant role, preventing oxidation, which induces apoptosis. However, its high content can increase the production of ATP (generated by mitochondria) inducing apoptosis in tumor cell lines, via a pro-oxidant mechanism. ${ }^{11}$ Studies show dose-dependent antineoplastic activity with influence on apoptosis, cell cycle, and cell signaling, increasing the cytotoxicity of the antineoplastic agent in cell lines of breast cancer treated with mitoxantrone and ascorbic acid. ${ }^{12}$

However, there are still many controversies regarding the role of vitamin $\mathrm{C}$ in the prevention and treatment of cancer. This review is aimed at the systematic mapping of ascorbic acid in the prevention and/or treatment of cancer in clinical and non-clinical studies from 2011 to 2015 , in order to understand dose-response variations as well as its mechanisms of action as an antioxidant and antitumor agent.

\section{Method}

The survey was conducted based on a literature review on Pubmed/Bireme databases, of scientific articles derived from clinical and non-clinical studies carried out between 2011 and 2015, using the keywords "cancer" and "ascorbic acid". Seventy-six articles were retrieved, of which 30 were used in the study as they met the inclusion criteria: clinical and non-clinical studies using ascorbic acid in the prevention and/or treatment of cancer between 2011 and 2015; and not the exclusion criteria: studies that do not use ascorbic acid in the treatment and/or prevention of cancer and who are outside the established time range (Figure 1). Of the articles selected for analysis, 12 used ascorbic acid as antioxidant: two clinical and ten nonclinical studies; 18 used it as pro-oxidant, of which only one was clinical, while the remaining (17) were non-clinical studies.

\section{Results AND DISCUSSION}

\section{Ascorbic acid as antioxidant}

Ascorbic acid is an essential micronutrient for human health, having antioxidant activity and participating in the production of proteins such as collagen, norepinephrine and serotonin. It is acquired through the ingestion of various plants, especially citrus fruits such as lemon and orange, and vegetables including tomatoes and broccoli, with recommended daily doses of $90 \mathrm{mg}$ for men and $75 \mathrm{mg}$ for women. ${ }^{13}$

Table 1 shows the clinical and non-clinical studies on the use of ascorbic acid as an antioxidant in the treatment and/or prevention of cancer, describing its use in several types of cancer or cell lines at different doses/concentrations and their mechanisms of action. The clinical studies (2) involved different types of cancer (pancreas, breast, kidney, lung, liver, bladder, lymphoma, prostate, colon, brain, leukemia, stomach, ovary, skin, and uterus) and doses of ascorbic acid (0.04-0.28 mM; 1-10 mM); the non-clinical studies (10) used different tumor cell lineages (MCF-7 cells in breast cancer; renal carcinoma; B16FO

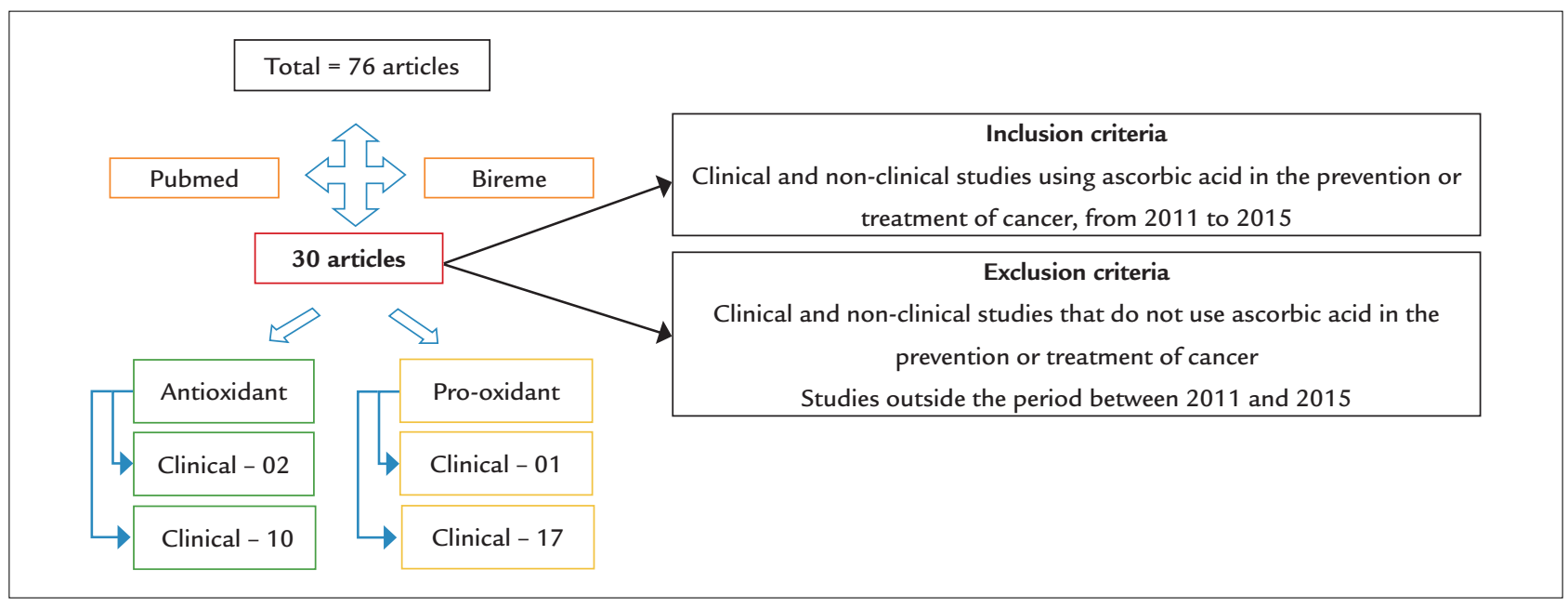

FIGURE 1 Literature search design with inclusion and exclusion criteria. 
TABLE 1 Clinical and non-clinical studies using ascorbic acid as antioxidant in the treatment and/or prevention of cancer.

\begin{tabular}{|c|c|c|c|c|}
\hline Study type & Type of cancer/cell & Mechanism of action & Dose/concentration & References \\
\hline Clinical & $\begin{array}{l}\text { Pancreas, breast, kidney, lung, liver, bladder, } \\
\text { lymphoma, prostate, colon, and stomach }\end{array}$ & $\begin{array}{l}\text { Decrease in levels of C-reactive protein and } \\
\text { proinflammatory cytokines }\end{array}$ & $0.04-0.28 \mathrm{mM}$ & $(25)$ \\
\hline Non-clinical & Breast cancer in mice & $\begin{array}{l}\text { Hinders metastases, tumor growth and } \\
\text { secretion of inflammatory cytokines, and } \\
\text { enhances tumoral encapsulation }\end{array}$ & $0.85 \mathrm{mM}$ & $(26)$ \\
\hline Non-clinical & MCF-7 cells in breast cancer & $\begin{array}{l}\text { Attenuation of cytotoxicity, decrease in } \\
\text { apoptosis, protection of neoplastic cells } \\
\text { against lipid peroxidation }\end{array}$ & 0.05 and $0.5 \mathrm{mM}$ & $(27)$ \\
\hline Non-clinical & MCF-7 cells in breast cancer & Decrease in cytotoxicity & $0.1 \mathrm{mM}$ & $(28)$ \\
\hline Clinical & $\begin{array}{l}\text { Pancreas, breast, kidney, lung, liver, bladder, } \\
\text { lymphoma, prostate, colon, brain, leukemia, } \\
\text { stomach, ovary, skin, and uterus }\end{array}$ & Decreased inflammation & $1-10 \mathrm{mM}$ & $(29)$ \\
\hline Non-clinical & Cells from renal carcinoma & Anti-apoptotic activity by recruiting $\mathrm{Bcl}-2$ & 0.11 and $2.28 \mathrm{mM}$ & $(30)$ \\
\hline Non-clinical & Cells from melanoma (B16FO) & Hinders metastases and tumor growth & $4 \mathrm{mM}$ & $(31)$ \\
\hline Non-clinical & Cells from cervical cancer (HeLa) & $\begin{array}{l}\text { Modulation of markers for cancer proliferation } \\
\text { (Ki67), invasion and metastasis (MMP-2 and } \\
\text {-9), angiogenesis (VEGF), apoptosis (TUNEL } \\
\text { and Bcl-2), and inflammation (COX-2, iNOS } \\
\text { and GST } \pi \text { ) }\end{array}$ & $4 \mathrm{mM}$ & $(32)$ \\
\hline Non-clinical & Lung cancer in ferrets & $\begin{array}{l}\text { Protection against lung injury induced by } \\
\text { exposure to cigarette smoke, by inhibiting } \\
\text { the expression of cyclin D1 }\end{array}$ & $1.2 \mathrm{mM}$ & (33) \\
\hline Non-clinical & Cells from neuroblastoma & Anti-apoptotic activity & $0.1-0.4 \mathrm{mM}$ & $(34)$ \\
\hline Non-clinical & Cells from acute lymphoblastic leukemia & $\begin{array}{l}\text { Decreased production of reactive oxygen } \\
\text { species caused by } 4 \text {-(hydroxyphenyl) } \\
\text { retinamide (4-HPR) }\end{array}$ & $100 \mu \mathrm{M}$ & $(35)$ \\
\hline Non-clinical & Cells from osteosarcoma (143-B) & Limitation of the invasive potential & $0.28 \mathrm{mM}$ & $(36)$ \\
\hline
\end{tabular}

Source: Literature search.

melanoma cells; HeLa cervical cancer cells; lung; neuroblastoma; cells from acute lymphoblastic leukemia; 143-B osteosarcoma cells), at varied doses/concentrations ( $0.85 \mathrm{mM}$; 0.05 and $0.5 \mathrm{mM} ; 0.1 \mathrm{mM} ; 0.11$ and $0.28 \mathrm{mM} ; 4 \mathrm{mM} ; 1.2 \mathrm{mM}$; 0.1-0.4 mM; $0.28 \mathrm{mM}$ ).

Plants and most animals synthesize ascorbic acid using glucose. Humans, however, do not synthesize this compound as the L-gulonolactone oxidase gene does not function, and thus this vitamin is obtained through the diet as ascorbate and dehydroascorbic acid (DHA). The normal concentration of ascorbic acid in human plasma is about 40 to $80 \mu \mathrm{M}$, and it is at this concentration range that endogenous vitamin $\mathrm{C}$ acts as an antioxidant. Physiological concentrations of ascorbate demonstrated inhibition of LDL oxidation and a synergistic action with vitamin E preventing lipid oxidation of cell membranes. ${ }^{14}$ Studies describe that intravenous ascorbic acid is more effective for raising serum levels of ascorbate than the form administered orally. ${ }^{15}$

Clinical studies showed that reductions in the levels of C-reactive protein and proinflammatory cytokines, resulting in decreased inflammation, are the main mechanisms antioxidant. Non-clinical studies, in turn, revealed attenuation of cytotoxicity, reduced apoptosis, protection of neoplastic cells against lipid peroxidation, modulation of markers of cancer proliferation (Ki67), invasion and metastasis (MMP-2 and -9), angiogenesis (VEGF), apoptosis (TUNEL and Bcl-2) and inflammation (COX-2, iNOS and GST $\pi$ ), decreased production of reactive oxygen species generated by 4-(hydroxyphenyl)retinamide (4-HPR), limitation of the invasive potential, also hindering metastases, tumoral growth and secretion of inflammatory cytokines, and enhancing tumor encapsulation, anti-apoptotic activity through $\mathrm{Bcl}-2$ recruitment and protection against lung 
injury induced by exposure to tobacco smoke, by inhibiting the expression of cyclin D1 (Table 1).

Vitamin $\mathrm{C}$ is an excellent reducing agent, which undergoes two successive oxidations to form the ascorbate radical (Asc ${ }^{\circ}$ ). Ascorbate is relatively unreactive due to the stability of the unpaired electron and oxidizes ascorbic acid to DHA; this reducing agent function is what maintains the structure of enzymes, thus allowing the biochemical machinery of cells and tissues functioning normally. ${ }^{14}$

Low electron potential and resonance stability is what makes it an antioxidant. The authors also reported that vitamin $C$ plays the role of collecting reactive oxygen species, acting as an antioxidant for maintaining the intracellular redox balance and minimizing the oxidative damage caused by these free radicals. ${ }^{16}$ Corroborating these studies, other researchers cite that nutrients like vitamin A, C, and $\mathrm{E}$ can neutralize reactive oxygen species, derived from the imbalance between antioxidant defenses and oxidative stress caused by diseases such as cancer or its treatment. Therefore, antioxidants, such as ascorbic acid, may assist in the prevention of cancer or its treatment, reducing side effects related to chemotherapy. ${ }^{17}$

\section{Ascorbic acid as an antitumor agent}

Vitamin supplementation can improve the benefits and quality of life of cancer patients. However, the literature shows controversy over the treatment of cancer including ascorbic acid. Researchers report that in vitro studies of neuroblastoma, bladder cancer, pancreatic cancer, and other tumor types showed cytotoxic effect of ascorbic acid, while in vivo studies supported this anti-cancer potential of the vitamin C..$^{18}$

Table 2 shows the clinical and non-clinical studies on the use of ascorbic acid as an antitumor agent in the treatment and/or prevention of cancer, describing its use in several types of cancer or cell lines at different doses/ concentrations and mechanisms of action. Of these, only one clinical study showed patients with metastatic pancreatic cancer treated with ascorbic acid at $0.28 ; 0.34$ and $0.56 \mathrm{mM}$ doses.

Regarding the non-clinical studies (17), they used different cancer cell lineages [IOSE-385, OVCAR-3, SKOV3 and OVCA-432 for ovary cancer; esophageal squamous cells and CP-A, CP-B, CP-C and CP-D for esophageal cancer; 23132/87 for gastric carcinoma, HT-29 colon cells, SKOV-3 ovary cells, BXPC-3 pancreatic cells, BT-20, MDAMB-468, MDA-MB-231 and MCF-7 breast cells, U-13898, U-87 and U-251 glioblastoma cells, umbilical vein endothelial cells (HUVECs) and NHDF cells; HeLa for cervical cancer; colon carcinoma; and HEp-2 cells for laryngeal carcinoma; SK-N-MC neuroblastoma cells; PANC-1, AsPC1, BxPC-3 and MIA PaCa-2 for pancreatic cancer; Epstein-Barr virus (EBV)-positive Burkitt's lymphoma and lymphoblastoid cells; PC3 prostate cancer cells; malignant pleural mesothelioma; NSCLC epithelial lung cancer; solid Ehrlich carcinoma; RKO and SW480 for colon cancer], in various concentrations of ascorbic acid $(0.25 \mathrm{mM}$; 0.1-2 mM; 0.3 mM; $0.5 \mathrm{mM}$; 0.005-0.1 mM; $4 \mathrm{mM} ; 28.39$ $\mathrm{mM}$; 3-10 mM; 1-6 mM; $4.26 \mathrm{mM} ; 22.71 \mathrm{mM} ; 0.4 \mathrm{mM}$; $11.36 \mathrm{mM}$; 0.5-5 mM; $0.68 \mathrm{mM}$; 1-3 mM).

At low millimolar concentrations, ascorbic acid is able to "kill" some cell lines in vitro, while in vivo it generates superoxide radicals, hydrogen peroxide, and extracellular ascorbyl responsible for its cytotoxic activity; however, concentrations as high as $20 \mathrm{mM}$ did not pose any risk to the lineage of non-malignant cells. ${ }^{19}$ Other studies confirm that high doses of ascorbic acid are effective in cell death as seen in in vitro studies as well as in vivo tumor growth inhibition. ${ }^{20}$ Corroborating this study, researchers describe that vitamin $C$ can be toxic in a selective manner in some types of tumor cells as a pro-oxidant, since concentrations above physiological $(0.1 \mathrm{mM})$, between $1 \mathrm{mM}$ and $10 \mathrm{mM}$, are toxic for neoplastic cells in vitro, for example, for melanoma and neuroblastoma cells, where concentrations from $10 \mathrm{nM}$ to $1 \mathrm{mM}$ can induce apoptosis. ${ }^{21}$

Regarding antitumor mechanism of action, the clinical study reported decreased tumor size. The non-clinical studies reported inhibited cell progression by increasing the levels of $\mathrm{H}_{2} \mathrm{O}_{2}$; anti-proliferative effect of tumor cells, through interference with cell cycle $\left(\mathrm{G}_{0} / \mathrm{G}_{1}\right)$ and generation of $\mathrm{H}_{2} \mathrm{O}_{2}$; cytotoxicity; modification of proteins related to apoptosis; reduction and inhibition of cell growth; reduction of serotonin levels, increasing degree of hemorrhagic necrosis and endothelial permeability; production of reactive oxygen species through the release of $\mathrm{Ca}_{2}{ }^{+}$; induced apoptosis; induced aponecrosis in cells resistant to apoptosis; inhibited cell proliferation and secretion of MMP-2 and -9, and increased secretion of TIMP-2; induced autophagy; tumor suppression; blockage of tumor progression and metastasis; activation of apoptosis and reactive oxygen species-dependent mechanisms; loss of cell viability; increased expression of $\mathrm{p} 53$; down-regulation of proteins (Sp1, Sp3 and Sp4) and decreased expression of genes that involve cell proliferation and angiogenesis (Table 2).

Vitamin C has been occasionally used to complement the treatment of cancer since 1974, aiding in patients' survival and quality of life. Studies in humans, animals, and in vitro show that antioxidants such as ascorbic acid, tocopherols, and carotenoids can inhibit the growth of neoplastic cells, inducing apoptosis, boost cell differen- 


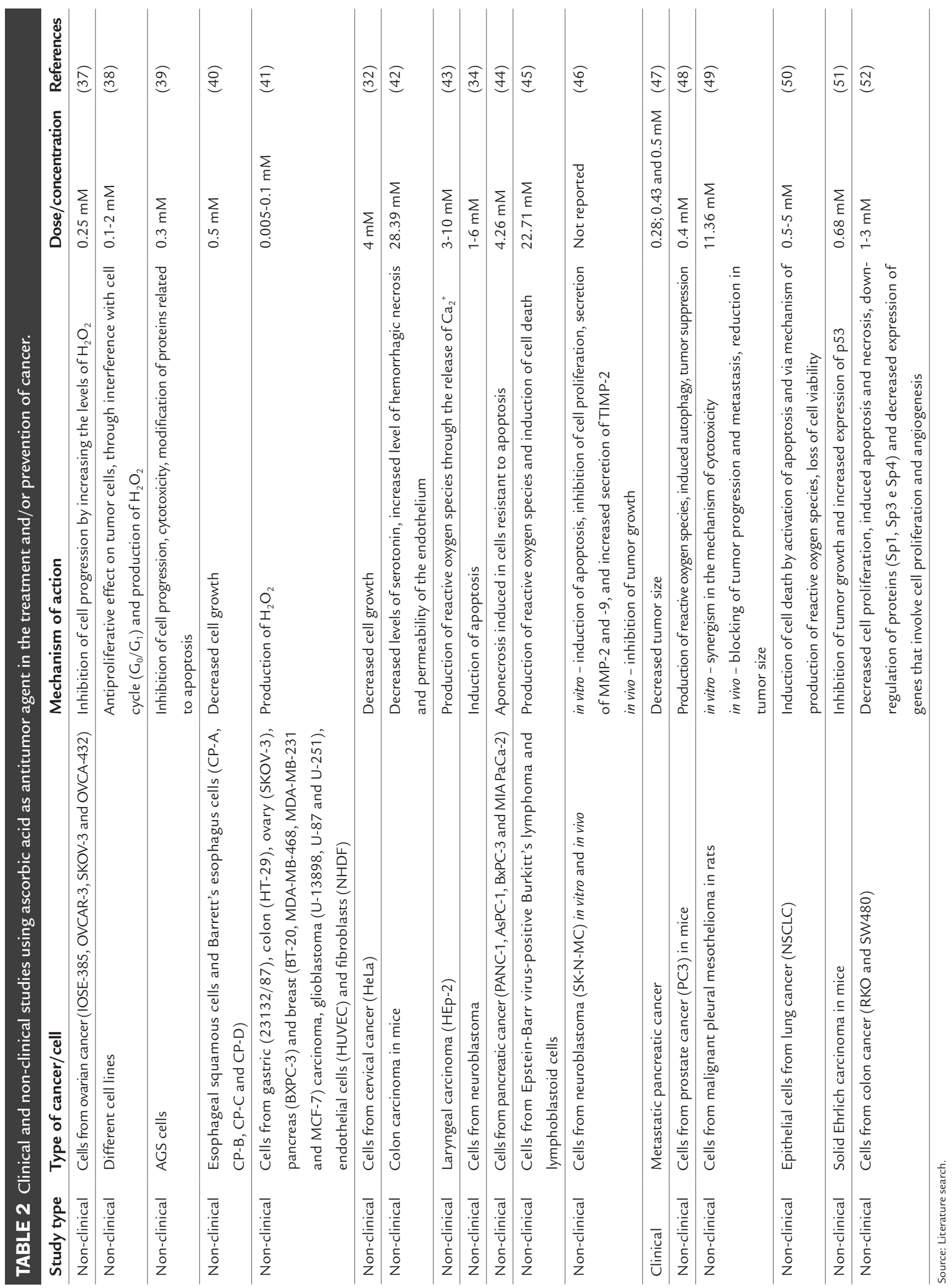


tiation and inhibiting the activity of protein kinase $\mathrm{C}$ and adenylyl cyclase, which proves its antitumor effect, also affirming that a high-dose therapy can benefit patients by improving their prognosis and therapeutic efficacy. ${ }^{22}$

Studies have reported that the pro-oxidant mechanisms of ascorbic acid include an ability to reduce metal ions such as $\mathrm{Fe}^{3+}$ and $\mathrm{Cu}^{3+}$, a process that generates free radicals such as hydroxyl radical, which interact with DNA, causing breaks in the phosphodiester bonds in addition modifications in the bases, generating induced cytotoxicity. ${ }^{23}$ Some research indicate another antitumor mechanism of action, the proliferation of natural killers (NK) cells without affecting its normal functions. According to them, these cells have the ability to "kill" tumor cells without the need for sensitization of direction, and that ascorbic acid promotes their proliferation. ${ }^{24}$

\section{Conclusion}

Studies have reported the use of ascorbic acid in the prevention and treatment of cancer. However, there is controversy about its antioxidant and antitumor role. This study revealed that there are reports in the literature of the effects of ascorbic acid at different doses/concentrations as antioxidant acting by several mechanisms, including the attenuation of cytotoxicity, reduced apoptosis, protection of neoplastic cells against lipid peroxidation, decrease in tumor growth and inflammatory cytokine secretion. And as an antitumor agent, ascorbic acid acts through the inhibition of cell progression, increased levels of $\mathrm{H}_{2} \mathrm{O}_{2}$, antiproliferative effect of tumor cells, cytotoxicity, induction of apoptosis, and more. There are also incompatibilities with regard to doses/concentration of ascorbic acid, as well as the need for characterization of clinical studies and mechanisms of action. Thus, other studies are needed to understand dose-response variations, as well as its targeting mechanisms of action, both as an antioxidant and antitumor agent, to assist treatment and prevention of cancer, aiming at better quality of life for both patients and the general population.

\section{ACKNOWLEDGMENTS}

We thank the Pharmaceutical Science Graduate Program at Universidade Federal do Piauí.

\section{Resumo}

Ácido ascórbico na prevenção e no tratamento do câncer

Este estudo de revisão teve como objetivo fazer o mapeamento sistemático do ácido ascórbico na prevenção e/ou no tratamento do câncer como antioxidante e/ou pró-oxidante em estudos clínicos e não clínicos, entre 2011 e 2015, para o entendimento das variações de dose-resposta, bem como dos seus mecanismos de ação como agente antioxidante e antitumoral. Nas bases de dados Pubmed e Bireme, foram identificados 78 artigos, dos quais apenas 30 apontavam o ácido ascórbico na prevenção e/ou no tratamento do câncer. Contudo, há controvérsias sobre as doses utilizadas e faltam estudos clínicos que caracterizem melhor o seu mecanismo de ação. Outros estudos devem ser realizados para o entendimento das variações de dose-resposta, bem como de seus mecanismos de ação, como agente antioxidante ou antitumoral, para auxiliar o tratamento e a prevenção do câncer, visando à melhor qualidade de vida dos pacientes e da população em geral.

Palavras-chave: neoplasias, câncer, prevenção, ácido ascórbico, antioxidantes.

\section{REFEREnCES}

1. Sung B, Prasad S, Yadav VR, Lavasanifar A, Aggarwal BB. Cancer and diet: how are they related? Free Radic Res. 2011; 45(8):864-79.

2. Greenman C, Stephens P, Smith R, Dalgliesh GL, Hunter C, Bignell G, et al. Patterns of somatic mutation in human cancer genomes. Nature. 2007; 446(7132):153-8.

3. Costa FF. Epigenomics in cancer management. Cancer Manag Res. 2010; 2:255-65.

4. Akladios FN, Andrew SD, Parkinson CJ. Selective induction of oxidative stress in cancer cells via synergistic combinations of agents targeting redox homeostasis. Bioorg Med Chem. 2015; 23(13):3097-104.

5. Reuter S, Gupta SC, Chaturvedi MM, Aggarwal BB. Oxidative stress, inflammation, and cancer: how are they linked? Free Radic Biol Med. 2010; 49(1):1603-16.

6. Rajakumar T, Pugalendhi P, Thilagavathi S. Dose response chemopreventive potential of allyl isothiocyanate against 7,12-dimethylbenz(a)anthracene induced mammary carcinogenesis in female Sprague-Dawley rats. Chem Biol Interact. 2015; 231:35-43

7. INCA. Instituto Nacional de Câncer José Alencar Gomes da Silva (INCA) Incidência de Câncer no Brasil. Estimativa 2014. Available from: http://www inca.gov.br/estimativa/2014/estimativa-24042014.pdf.

8. Lee BL, Liedke PE, Barrios CH, Simon SD, Finkelstein DM, Goss PE. Breast cancer in Brazil: present status and future goals. Lancet Oncol. 2012; 13(3):e95-102.

9. Xiao H, Liang H, Wang JB, Huang CY, Wei WQ, Boniol M, et al. Attributable causes of cancer in China: fruit and vegetable. Chin J Cancer Res. 2011; 23(3):171-6.

10. INCA. Instituto Nacional de Câncer José Alencar Gomes Silva (INCA) Consenso Nacional de Nutrição Oncológica. v. 2; 2011. Available from: http://www1.inca.gov.br/inca/Arquivos/consenso_nutricao_vol2.pdf.

11. González MJ, Rosario-Pérez G, Guzmán AM, Miranda-Massari JR, Duconge J, Lavergne J, et al. Mitochondria, energy and cancer: the relationship with ascorbic acid. J Orthomol Med. 2010; 25(1):29-38.

12. Guerriero E, Sorice A, Capone F, Napolitano V, Colonna G, Storti G, et al. Vitamin C effect on mitoxantrone-induced cytotoxicity in human breast cancer cell lines. PloS One. 2014; 9(12):e115287.

13. Aditi A, Graham DY. Vitamin C, gastritis, and gastric disease: a historical review and update. Dig Dis Sci. 2012; 57(10):2504-15.

14. Du J, Cullen JJ, Buettner GR. Ascorbic acid: chemistry, biology and the treatment of cancer. Biochim Biophys Acta. 2012; 1826(2):443-57.

15. Mandl J, Szarka A, Bánhegyi G. Vitamin C: update on physiology and pharmacology. Br J Pharmacol. 2009; 157(7):1097-110. 
16. Rahal A, Kumar A, Singh V, Yadav B, Tiwari R, Chakraborty S, et al. Oxidative stress, prooxidants, and antioxidants: the interplay. Biomed Res Int. 2014; 2014:761264.

17. Portantiolo TN, Vale IAV, Bergman RB, Alib RT. Consumo de vitaminas antioxidantes por mulheres com câncer de mama submetidas ao tratamento quimioterápico na cidade de Pelotas-RS. Rev Bras Cancerol. 2014; 60(4):323-9.

18. Ichim TE, Minev B, Braciak T, Luna B, Hunninghake R, Mikirova NA, et al. Intravenous ascorbic acid to prevent and treat cancer-associated sepsis? J Transl Med. 2011; 9:25

19. Mccarty MF, Contreras F. Increasing superoxide production and the labile iron pool in tumor cells may sensitize them to extracellular ascorbate. Front Oncol. 2014; 4:249.

20. Takemura Y, Satoh M, Satoh K, Hamada H, Sekido Y, Kubota S. High dose of ascorbic acid induced cell death in mesothelioma cells. Biochem Biophys Res Commun. 2010; 394(2):249-53.

21. Park S. The effects of high concentrations of vitamin $\mathrm{C}$ on cancer cells. Nutrients. 2013; 5(9):3496-505.

22. Gröber, U. Antioxidants and other micronutrients in complementary oncology. Breast Care (Basel). 2009; 4(1):13-20.

23. Putchala MC, Ramani P, Sherlin HJ, Premkumar P, Natesan A. Ascorbic acid and its pro-oxidant activity as a therapy for tumours of oral cavity: a systematic review. Arch Oral Biol. 2013; 58(6):563-74.

24. Huijskens MJAJ, Walczak M, Sarkar S, Atrafi F, Senden-Gijsbers BL, Tilanus MG, et al. Ascorbic acid promotes proliferation of natural killer cell populations in culture systems applicable for natural killer cell therapy. Cytotherapy. 2015; 17(5):613-20.

25. Mikirova N, Casciari J, Rogers A, Taylor P. Effect of high-dose intravenous vitamin C on inflammation in cancer patients. J Transl Med. 2012; 10:189.

26. Cha J, Roomi W, Ivanov V, Kalinovsky T, Neidzwuiecki A, Rath M. Ascorbate supplementation inhibits growth and metastasis of B16FO melanoma and 4T1 breast cancer cells in vitamin C-deficient mice. Int J Oncol. 2013; 42(1):55-64.

27. Subramani T, Yeap SK, Ho WY, Ho CL, Omar AR, Aziz SA, et al. Vitamin C suppresses cell death in MCF-7 human breast cancer cells induced by tamoxifen. J Cell Mol Med. 2014; 18(2):305-13.

28. Tor YS, Yazan LS, Foo JB, Wibowo A, Ismail N, Cheah YK, et al. Induction of apoptosis in MCF-7 cells via oxidative stress generation, mitochondria dependent and caspase-independent pathway by ethyl acetate extract of Dillenia suffruticosa and its chemical profile. Plos One. 2015; 10(6):e0127441.

29. Mikirova N, Casciari J, Riordan N, Hunninghake R. Clinical experience with intravenous administration of ascorbic acid: achievable levels in blood for different states of inflammation and disease in cancer patients. J Transl Med. 2011; 11:191.

30. Garg NK, Mangal S, Sahu T, Mehta A, Vyas SP, Tyagi RK. Evaluation of antiapoptotic activity of different dietary antioxidants in renal cell carcinoma against hydrogen peroxide. Asian Pac J Trop Biomed. 2011; 1(1):57-63.

31. Roomi MW, Kalinovsky T, Roomi NW, Niedzwiecki A, Rath M. Suppression of metastasis of intratesticular inoculation of B16FO melanoma cells by a novel nutrient mixture in male athymic nude mice. Exp Ther Med. 2012; 4(5):775-80.

32. Roomi MW, Cha J, Kalinovsky T, Roomi NW, Niedzwiecki A, Rath M. Effects of a nutrient mixture on immunohistochemical localization of cancer markers in human cervical cancer HeLa cell tumor xenografts in female nude mice. Exp Ther Med. 2015; 9(2):294-302.

33. Kim Y, Chongviriyaphan N, Liu C, Russel RM, Wang XD. Combined $\alpha$-tocopherol and ascorbic acid protects against smoke-induced lung squamous metaplasia in ferrets. Lung Cancer. 2012; 75(1):15-23.

34. Hardaway CM, Badisa RB, Soliman KFA. Effect of ascorbic acid and hydrogen peroxide on mouse neuroblastoma cells. Mol Med Report. 2012; 5(6):1449-52.

35. Apraiz A, Idkowiak-Baldys J, Nieto-Rementerva N, Boyano MD, Hannum YA, Asumendi A. Dihydroceramide accumulation and reactive oxygen species are distinct and non essential events in 4-HPR mediated leukemia cell death. Biochem Cell Biol. 2012; 90(2):209-23.
36. Cmoch A, Podszywalow-Bartnicka P, Palczewska M, Piwock K, Groves P, Pikula S. Stimulators of mineralization limit the invasive phenotype of human osteosarcoma cells by a mechanism involving impaired invadopodia formation. Plos One. 2014; 9(10):e109938.

37. Li HH, Zhao YJ, Li Y, Dai CF, Jobe SO, Yang XS, et al. Estradiol $17 \mathrm{~b}$ and its metabolites stimulate cell proliferation and antagonize ascorbic acid suppressed cell proliferation in human ovarian cancer cells. Reprod Sci. 2014; 21(1):102-11.

38. Fromberg A, Gutsch D, Schulze D, Vollbracht C, Weiss G, Czubayko F, et al. Ascorbate exerts anti-proliferative effects through cell cycle inhibition and sensitizes tumor cells towards cytostatic drugs. Cancer Chemother Pharmacol. 2011; 67(5):1157-66.

39. Naggapan A, Park HS, Park KI, Kim JA, Hong GE, Kang SR, et al. Proteomic analysis of differentially expressed proteins in vitamin C-treated AGS cells. BMC Biochem. 2013; 14:24

40. Merlo LMF, Kosoff RE, Gardiner KL, Maley CC. An in vitro co-culture model of esophageal cells identifies ascorbic acid as a modulator of cell competition. BMC Cancer. 2011; 11:461.

41. Klingelhoeffer C, Kämmerer U, Koospal M, Mühling B, Schneider M, Kapp $\mathrm{M}$, et al. Natural resistance to ascorbic acid induced oxidative stress is mainly mediated by catalase activity in human cancer cells and catalase-silencing sensitizes to oxidative stress. BMC Complement Altern Med. 2012; 12:61.

42. Baguley BC, Ding Q, Richardson E. Preliminary evidence that high-dose vitamin $C$ has a vascular disrupting action in mice. Front Oncol. 2014; 4:310.

43. Martinovich GG, Golubeva EM, Martinovich IV, Cherenkevich SN. Redox regulation of calcium signaling in cancer cells by ascorbic acid involving the mitochondria electron transport chain. J Biophy. 2012; 2012:921653.

44. Dinnen RD, Mao Y, Qiu W, Cassai N, Slavkovich VN, Nichols G, et al. Redirecting apoptosis to aponecrosis induces selective cytotoxicity to pancreatic cancer cells through increased ROS, decline in ATP levels and VDAC. Mol Cancer Ther. 2013; 12(12):2792-803.

45. Shatzer AN, Espey MG, Chavez M, Tu H, Levine M, Cohen JI. Ascorbic acid kills Epstein-Barr virus positive Burkitt lymphoma cells and Epstein-Barr virus transformed B-cells in vitro, but not in vivo. Leuk Lymphoma. 2013; 54(5):1069-78.

46. Waheed Roomi M, Cha J, Kalinovsky T, Roomi NW, Niedzwiecki A, Rath $\mathrm{M}$. Inhibition of the SK-N-MC human neuroblastoma cell line in vivo and in vitro by a novel nutrient mixture. Oncol Rep. 2013; 29(5):1714-20.

47. Monti DA, Mitchell E, Bazzan AJ, Littman S, Zabrecky G, Yeo CJ, et al. Phase I evaluation of intravenous ascorbic acid in combination with gemcitabine and erlotinib in patients with metastatic pancreatic cancer. Plos One. 2012; 7(1):e29794.

48. Tomasetti M, Nocchi L, Neuzil J, Goodwin J, Nguyen M, Dong L, et al. Alphatocopheryl succinate inhibits autophagic survival of prostate cancer cells induced by vitamin K3 and ascorbate to trigger cell death. PLoS One. 2012; 7(12):e52263.

49. Volta V, Ranzato E, Martinotti S, Gallo S, Russo MV, Mutti L, et al. Preclinical Demonstration of Synergistic Active Nutrients/Drug (AND) combination as a potential treatment for malignant pleural mesothelioma. Plos One. 2013; 8(3):e58051.

50. Vuyyuri SB, Rinkinen J, Worden E, Shim H, Lee S, Davis KR. Ascorbic acid and a cytostatic inhibitor of glycolysis synergistically induce apoptosis in non-small cell lung cancer cells. Plos One. 2013; 8(6):e67081.

51. Bassiony H, Sabet S, El-Din TAS, Mohamed MM, El-Ghor AA. Magnetite nanoparticles inhibit tumor growth and upregulate the expression of P53/P16 in Ehrlich solid carcinoma bearing mice. Plos One. 2014; 9(11):e111960.

52. Pathi SS, Lei P, Sreevalsan S, Chadalapaka G, Jutooru I, Safe S. Pharmacologic doses of ascorbic acid repress specificity protein (sp) transcription factors and sp-regulated genes in colon cancer cells. Nutr Cancer. 2011; 63(7):1133-42. 